\title{
PENINGKATAN PEMAHAMAN KONSEP MATEMATIKA MELALUI REALISTIC MATHEMATIC EDUCATION BERBANTU ALAT PERAGA BONGPAS
}

\author{
Achmad Gilang Fahrudhin ${ }^{1 凶}$, Eka Zuliana ${ }^{2}$, dan Henry Suryo Bintoro ${ }^{3}$ \\ ${ }^{1,2}$ Prodi Pendidikan Guru Sekolah Dasar, Universitas Muria Kudus \\ ${ }^{3}$ Prodi Pendidikan Matematika, Universitas Muria Kudus
}

\begin{tabular}{l}
\hline Info Artikel \\
\hline Sejarah Artikel: \\
Diterima 24 Feb 2018 \\
Direvisi 20 Mar 2018 \\
Disetujui 20 Apr 2018 \\
\hline
\end{tabular}

Keywords: Realistic Mathematic Education, Bongpas Viewer Tool, Ability to Understand Concepts, Cube Volume and Blocks

Paper type:

Research paper

\begin{abstract}
The purpose of this study is to describe the improvement of the ability to comprehend the concept of mathematics, teacher's teaching skills in managing mathematics learning and student learning activities using Realistic Mathematic Education model assisted BongPas props. The subjects of this study are class V SD 2 Bae, amounting to 14 people consisting of 6 male students and 8 female students. Data collection techniques used are observation, interview, test and documentation. Data analysis in this classroom action research is quantitative and qualitative data analysis. The results showed the ability of understanding the concept of mathematics in the first cycle is $35.7 \%$ with less criteria and the second cycle is $78.5 \%$ with good criteria. The result of observation of teacher's teaching skill in managing learning has increased, from cycle I get percentage of $76 \%$ with good criterion, while cycle II get $86,5 \%$ percentage with very good criterion. The observation of student learning activity has increased, from cycle I with percentage of $71 \%$ with good criterion while cycle II with percentage $82 \%$ with very good criterion. Based on the research that has been done, it can be concluded that the ability of understanding the concept of mathematics, teaching skills of teachers in managing learning and learning activities of students in grade V SD 2 Bae increased after the implementation of Realistic Mathematic Education model assisted BongPas props.
\end{abstract}

\section{Abstrak}

Tujuan penelitian ini adalah untuk mendeskripsikan peningkatan kemampuan pemahaman konsep matematika, keterampilan mengajar guru dalam mengelola pembelajaran matematika dan aktivitas belajar siswa menggunakan model Realistic Mathematic Education berbantu alat peraga BongPas. Subjek penelitian ini yaitu kelas V SD 2 Bae yang berjumlah 14 orang yang terdiri dari 6 siswa lakilaki dan 8 siswa perempuan. Teknik pengumpulan data yang digunakan yaitu observasi, wawancara, tes dan dokumentasi. Analisis data dalam penelitian tindakan kelas ini adalah analisis data kuantitatif dan kualitatif. Hasil penelitian menunjukkan kemampuan pemahaman konsep matematika pada siklus I yaitu 35,7\% dengan kriteria kurang dan pada siklus II yaitu 78,5\% dengan kriteria baik. Hasil pengamatan keterampilan mengajar guru dalam mengelola pembelajaran mengalami peningkatan, dari siklus I memperoleh persentase $76 \%$ dengan kriteria baik, sedangkan siklus II memperoleh persentase $86,5 \%$ dengan kriteria sangat baik. Hasil pengamatan aktivitas belajar siswa mengalami peningkatan, dari siklus I dengan persentase $71 \%$ dengan kriteria baik sedangkan siklus II dengan persentase $82 \%$ dengan kriteria sangat baik. Berdasarkan penelitian yang telah dilakukan, maka dapat disimpulkan bahwa kemampuan pemahaman konsep matematika, keterampilan mengajar guru dalam mengelola pembelajaran dan aktivitas belajar siswa di kelas $\mathrm{V}$ SD 2 Bae meningkat setelah diterapkannya model Realistic Mathematic Education berbantu alat peraga BongPas.

\footnotetext{
$\triangle$ Alamat korespondensi:

Program Studi Pendidikan Matematika, Universitas Muria Kudus

Kampus UMK Gondangmanis, Bae Kudus Gd. L lantai 1 Ruang 2 PO BOX 53 Kudus

Tlp. (0291) 438229 Fax. (0291) 437198

E-mail: fahrudhingilang@yahoo.com
} 


\section{PENDAHULUAN}

Sekolah dasar merupakan lembaga pertama bagi peserta didik untuk belajar membaca, menulis terutama berhitug. Kemampuan berhitung di sekolah dasar memiliki beberapa tujuan diantaranya menanamkan dan meletakkan landasan berhitung yang kuat untuk mempelajari pengetahuan tentang matematika. Selain itu, agar siswa tidak akan merasa asing dengan matematika dan sedikit demi sedikit siswa akan menyukai pelajaran matematika.

Matematika mempunyai peranan yang sangat penting dalam kehidupan sehari-hari maupun dalam membantu bidang ilmu lainnya. Mengingat pentingnya peranan matematika, timbul harapan agar pemahaman konsep siswa dalam matematika dapat ditingkatkan. Tetapi dalam kenyataan menunjukkan pemahaman konsep siswa masih tergolong sangat rendah. Hal ini disebabkan karena masih banyaknya anggapan siswa yang kurang positif terhadap matematika (Widari, 2013:190).

Pemahaman konsep merupakan kemampuan yang berkenaan dengan memahami ide-ide matematika yang menyeluruh dan fungsional. Pemahaman konsep lebih penting daripada sekedar menghafal. Oleh karena itu, jangan salah dalam memberikan arahan atau bimbingan kepada siswa. Karena salah sedikit memberikan arahan kepada siswa pasti konsep yang akan dipahami siswa tidak akan bisa dipahami oleh siswa (Karunia, 2015:81).

Berdasarkan hasil observasi yang dilakukan di kelas V SD 2 Bae menyatakan bahwa pada umumnya di sekolah tersebut pembelajaran dengan menggunakan metode ceramah dan pemberian tugas mandiri, namun metode ini tidak dapat mengatasi masalah pemahaman konsep siswa. Meskipun sudah dilakukan berbagai cara untuk meningkatkan pemahaman konsep siswa, seperti diadakannya remidial bagi siswa yang nilainya tidak mencapai standar ketuntasan dan memberi tugas pengembangan materi yang berupa soal. Tetapi belum bisa mengatasi masalah pemahaman konsep siswa.

Menurut Lestari (2015:40), model realistic mathematic education adalah matematika sekolah yang dilaksanakan dengan menempatkan realitas dan pengalaman siswa sebagai titik awal pembelajaran. Masalahmasalah realistik digunakan sebagai sumber munculnya konsep-konsep matematika atau pengetahuan matematika atau pengetahuan matematika formal yang dapat mendorong aktivitas penyelesaian masalah, mencari masalah, dan mengorganisasi pokok persoalan. Cara ini diharapkan dapat meningkatkan kemampuan pemahaman konsep siswa mengenai matematika menjadi lebih baik dari sebelumnya.

Selain penggunaan model pembelajaran realistic mathematic education yang dianggap bisa meningkatkan kemampuan pemahaman konsep siswa, penggunaan alat peraga juga diharapkan mampu meningkatkan kemampuan pemahaman konsep siswa pada materi volume kubus dan balok. Alat peraga bongkar pasang tersebut terbuat dari bahan utama sterofom dan mika tebal. Mika tebal berguna untuk membentuk bangun kubus besar dan balok besar serta sterofom berguna untuk membuat kubus satuan yang berguna untuk mengisi kubus besar dan balok besar untuk mengetahui volume kubus dan baloknya. Siswa dapat membongkar dan memasang kembali dengan mudah alat peraga Bongkar pasang ini. Serta alat peraga tersebut dibuat tiga dimensi, agar siswa bisa melihat dan menyentuh langsung alat peraga bongkar pasang ini.

Berdasarkan uraian yang telah dijabarkan sebelumnya, maka tujuan yang ingin dicapai dalam penelitian ini adalah untuk mendeskripsikan keterampilan guru, aktivitas belajar siswa dan kemampuan pemahaman konsep siswa menggunakan model realistic mathematic education berbantu alat peraga bongpas pada materi volume kubus dan balok di kelas V SD 2 Bae semester 1 tahun pelajaran 2017/2018.

Pemahaman konsep adalah salah satu kecakapan atau kemampuan untuk memahami dan menjelaskan suatu situasi atau tindakan suatu kelas atau kategori, yang memiliki sifat-sifat umum yang diketahuinya dalam matematika (Rahayu, 2012:11). Menurut Susanto (2013:210), pemahaman konsep adalah kemampuan menjelaskan suatu situasi dengan kata-kata yang berbeda dan dapat menginterpretasikan atau menarik kesimpulan dari tabel, data, grafik, dan sebagainya.

Langkah-langkah yang diperhatikan untuk pemahaman konsep menurut Salimi (dalam Susanto, 2013:209), indikator pemahaman konsep meliputi: 1) Mendefinisikan konsep secara verbal dan tulisan, 2) Membuat contoh dan non contoh penyangkal, 3) Mempresentasikan suatu konsep dengan model, diagram, dan simbol, 4) Mengubah suatu bentuk representasi ke bentuk lain, 5) Mengenal berbagai makna dan interpretasi konsep, 6) Mengidentifikasi sifat-sifat suatu konsep dan mengenal syarat-syarat yang menentukan suatu konsep, 7) Membandingkan dan membedakan konsep-konsep.

Salah satu model pembelajaran yang diterapkan untuk meningkatkan kemampuan 
berpikir kreatif matematika adalah model Realistic Mathematic Education (RME). Ilma (2007:47), realistic mathematic education adalah suatu pendekatan pembelajaran matematika yang bertitik tolak dari hal-hal yang real bagi siswa. serta matematika harus dihubungkan dengan kenyataan, berada dekat dengan peserta didik, dan relevan dengan kehidupan masyarakat agar memiliki nilai manusiawi. Selanjutnya Realistic mathematic education adalah suatu teori dalam pendidikan matematika yang berdasarkan pada ide yang dikemukakan oleh Freudenthal bahwa matematika adalah aktivitas manusia dan matematika harus dihubungkan secara nyata terhadap konteks kehidupan sehari-hari (Naswandi dalam Hazami, 2013:215-216).

Menurut Suwarsono (dalam Hobri, 2009:173-174) kelebihan-kelebihan model realistic mathematic education (RME) adalah sebagai berikut: 1) RME memberikan pengertian yang jelas dan operasional kepada siswa tentang keterkaitan antara matematika dengan kehidupan sehari-hari dan tentang kegunaan matematika pada umumnya kepada manusia, 2) RME memberikan pengertian yang jelas dan operasional kepada siswa bahwa matematika adalah suatu bidang kajian yang dapat dikontruksi dan dikembangkan sendiri oleh siswa dan oleh setiap orang "biasa" yang lain, tidak hanya oleh mereka yang disebut pakar dalam bidang tersebut, 3) RME memberikan pengertian yang jelas dan operasional kepada siswa bahwa cara penyelesaian suatu soal atau masalah tidak harus tunggal, dan tidak harus sama antara orang satu dengan orang yang lain, 4) RME memberikan pengertian yang jelas dan operasional kepada siswa bahwa dalam mempelajari matematika, proses pembelajaran merupakan suatu yang utama dan untuk mempelajari matematika orang harus menjalani sendiri proses itu dan berusaha untuk menemukan sendiri konsep-konsep dan materimateri matematika yang lain dengan bantuanpihak lain yang sudah tahu (guru), 5) RME memadukan kelebihan-kelebihan dari berbagai pendekatan pembelajaran lain yang juga dianggap "unggul", 6) RME bersifat lengkap, mendetail dan operasional. Proses pembelajaran topik-topik matematika dikerjakan secara menyeluruh, mendail dan operasional sejak dari pengembangan kurikulum, pengembangan didaktiknya di kelas, yang tidak hanya secara makro tapi juga secara mikro beserta proses evaluasinya.

Kelemahan-kelemahan model Realistic Mathematic Education (RME) menurut Suwarsono (dalam Hobri, 2009:175-176) adalah sebagai berikut: 1) Pemahaman tentang RME dan pengimplementasian RME membutuhkan paradigma. Perubahan paradigma ini mudah diucapkan tetapi tidak mudah untuk dipraktekkan karena paradigma lama sudah begitu kuat dan lama mengakar, 2) Pencarian soal-soal yang kontekstual, yang memenuhi syarat-syarat yang dituntut oleh RME tidak selalu mudah untuk setiap topik matematika yang perlu disajikan siswa, terlebih karen asoal tersebut masingmasing harus bisa diselesaikan dengan berbagai cara, 3) Upaya mendorong siswa agar bisa menemukan cara untuk menyelesaikan tiap soal juga merupakan tantangan sendiri, 4) Proses pengembangan kemampuan berpikir siswa dengan memulai soal-soal kontekstual dengan mekanisme berpikir siswa harus diikuti dengan cermat agar guru bisa membantu siswa dalam menemukan kembali terhadap konsep-konsep matematika tertentu, 5) Pemilihan alat peraga harus cernat agar alat peraga yang dipilih bisa membantu proses berpikir siswa sesuai dengan tuntutan RME, 6) Penilaian (asesment) dalam RME lebih rumit daripada dalam pembelajaran konvensional, 7) Kepadatan materi pembelajaran dalam kurikulum perlu dikurangi secara substansial, agar proses pembelajaran siswa bisa berlangsung sesuai dengan prinsip-prinsip RME.

Pembelajaran dengan menggunakan model Realistic Mathematic Education terdiri dari beberapa langkah. Hobri (2009: 168-170), langkah-langkah model Realistic Mathematic Education, meliputi: 1) Menggunakan masalah kontekstual (the use of contex), 2) Menggunakan model (use models, bridging by verti instrument), 3) Menggunakan kontribusi siswa (student contribution), 4) Interaktivitas (interactivity), 5) Terintegrasi dengan topik lainnya (intertwining).

Menurut Alfirdausi (2011:28), alat peraga adalah sebuah atau seperangkat benda konkrit yang dibuat, dirancang, dihimpun atau disusun secara sengaja, yang digunakan untuk membantu menanamkan atau mengembangkan konsepkonsep dalam matematika. Selanjutnya menurut Pujiati (2004:3), alat peraga merupakan media pengajaran yang membawakan konsep-konsep yang dipelajari. Alat peraga tersebut dapat menyajikan hal-hal yang abstrak dalam bentuk benda-benda atau fenomen-fenomena konkrit yang dapat dilihat, dipegang, diubah-ubah sehingga hal-hal yang abstrak lebih mudah dipahami oleh siswa.

Menurut Hamalik (dalam Rahadi, 2003:24), manfaat praktis alat peraga diantaranya, sebagai berikut: 1) Memungkinkan adanya interaksi langsung antara siswa dengan lingkungan, 2) Dapat menghasilkan keseragaman pengamatan oleh siswa, 3) Menanamkan konsep dasar yang besar, konkrit dan realistik, 4) 
Membangkitkan keingintahuan, kesukaan dan minat yang baru, 5) Membangkitkan motivasi dan merangsang siswa belajar, 6) Memberikan pengalaman yang integral dari suatu yang konkrit sampai kepada yang abstrak.

Alat peraga BongPas adalah alat peraga yang terbat dari sterofom yang dipotong menjadi kubus satuan dan bahan untuk membuat kubus besar dan balok besar terbuat dari mika tebal yang masing-masing bahan aman bagi anak-anak ketika digunakan. Selain itu, dengan menggunakan alat peraga tersebut siswa menjadi lebih mudah untuk membongkar untuk mengetahui rumus dari volume kubus dan balok. Media bongkar pasang adalah media tiga dimensi yang bersifat visual karena dalam penggunannya lebih memanfaatkan indera penglihatan. Media tersebut memiliki konsep seperti pada puzzle tetapi lebih mendapatkan modifikasi di bagian tertentu sehingga sesuai dengan materi pembelajaran dan tujuan pembelajaran yang hendak dicapai (Masruroh, Intan dan Purwanto, 2013:3).

\section{METODE PENELITIAN}

Penelitian ini merupakan Penelitian Tindakan Kelas (PTK). Arikunto (2014: 58) penelitian tidakan kelas adalah penelitan tindakan (action research) yang dilakukan dengan tujuan memperbaiki mutu praktik pembelajaran di kelasnya. Subjek penelitian siswa kelas V SD 2 Bae dengan jumlah siswa 14 orang terdiri dari 6 siswa laki-laki dan 8 siswa perempuan. Variabel dalam penelitian ini ada dua, yaitu variable bebas (model realistics mathematics education berbantuan media bongpas) dan variabel terikat (kemampuan pemahaman konsep).

Desain penelitian yang digunakan adalah penelitian model Kemmis dan Mc Taggart. Arikunto (2006: 97) penelitian tindakan kelas model Kemmis dan Mc Taggart terdiri dari empat komponen, yaitu perencanaan (planning), tindakan (acting), observasi (observing), dan refleksi (reflecting) dalam suatu sistem spiral yang saling terkait antara langkah satu dengan langkah berikutnya yang dapat dilihat pada Gambar 1 berikut ini.

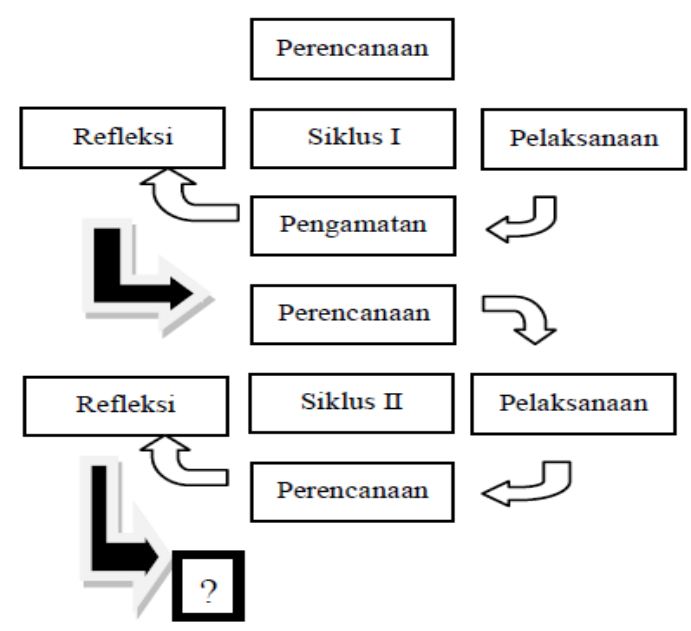

Gambar 1. PTK Model Kemmis dan Mc Taggart Teknik pengumpulan data yang digunakan yaitu observasi, wawancara, tes dan dokumentasi. Instrumen pada penelitian ini menggunakan soal tes, lembar observasi, lembar wawancara dan dokumentasi. Analisis data dalam penelitian ini adalah analisis data kuantitatif dan kualitatif. Data kuantitatif yaitu data mentah yang diperoleh dari hasil tes kemampuan pemahaman konsep matematika, kemudian dianalisis dengan menentukan nilai tes kemampuan pemahaman konsep, nilai rata-rata kelas, nilai rata-rata tiap indikator pemahaman konsep, dan ketuntasan klasikal. Data kualitatif yaitu data yang diperoleh dari hasil pengamatan aktivitas belajar siswa dan keterampilan guru dalam pengelolaan pembelajaran yang dianalisis menggunakan rating scale. Sugiyono (2013: 141) mendeskripsikan bahwa rating scale merupakan data mentah yang diperoleh berupa angka kemudian ditafsirkan dalam pengertian kualitatif.

\section{HASIL DAN PEMBAHASAN}

Hasil wawancara dengan guru dan siswa ketika prasiklus diperoleh data bahwa guru tidak pernah menggunakan model pembelajaran untuk menunjang pembelajaran menjadi lebih baik, guru juga enggan menggunakan alat peraga yang sesuai dengan materi yang akan diajarkan. Jadi, guru hanya menggunakan metode ceramah yang membuat siswa menjadi bosan bahkan tidak suka dengan pelajaran matematika. Karena menurut mereka, pembelajaran matematika sangat sulit dan dijadikan momok pelajaran. Hasil hasil tes kemampuan berpikir kreatif pra siklus ada 4 siswa $(28,75 \%)$ yang tuntas KKM yang ditentukan sedangkan 10 siswa $(71,43 \%)$ tidak tuntas KKM dengan kriteria ketuntasan minimal adalah 70. Sedangkan rata-rata nilai prasiklus dari kemampuan berpikir kreatif siswa adalah 62,35 dengan kriteria cukup baik. 
Penelitian siklus I dilaksanakan pada hari Rabu tanggal 06 September 2017 dan hari Kamis tanggal 07 September 2017 2017. Penelitian siklus II dilaksanakan pada hari Rabu tanggal 13 September 2017 dan hari Sabtu tanggal 16 September 2017. Setiap pertemuan dilaksanakan selama 2 jam pelajaran $(2 \times 35$ menit $)$. Berdasarkan pelaksanaan tindakan penerapan model Realistic Mathematic Education berbantu alat peraga BongPas dalam pelaksanaan pembelajaran di kelas V SD 2 Bae, maka dapat diketahui keterampilan guru dalam mengelola pembelajaran, aktivitas belajar siswa dan pemahaman konsep matematika siswa mengalami peningkatan dari siklus I ke siklus II. Pada siklus I dan siklus II telah dilaksanakan tes untuk mengukur kemampuan pemahaman konsep matematika siswa yang dilaksanakan di akhir siklus, selain itu juga dilaksanakan observasi untuk mengamati keterampilan guru dalam pengelolaan pembelajaran dan aktivitas belajar siswa.

Hasil penelitian kemampuan pemahaman konsep siswa menunjukkan bahwa pada siklus I memperoleh persentase $62 \%$ dengan kriteria baik, sedangkan siklus II memperoleh persentase $76,1 \%$ dengan kriteria baik. Untuk memperjelas perbandingan hasil pengamatan kemampuan konsep matematika siswa pada siklus I dan II dapat dilihat pada Gambar 2 berikut ini.

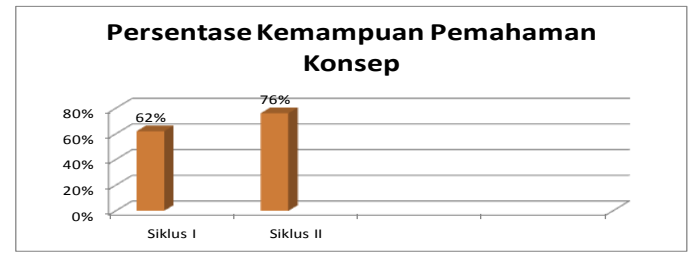

Gambar 2. Diagram Batang Persentase Kemampuan Pemahaman Konsep

Hasil observasi keterampilan guru dalam mengelola pembelajaran pada siklus I memperoleh persentase $76 \%$ dengan kriteria baik dan meningkat pada siklus II memperoleh persentase $86,5 \%$ dengan kriteria sangat baik. Untuk memperjelas perbandingan hasil pengamatan keterampilan guru dalam mengelola pembelajaran pada siklus I dan II dapat dilihat pada Gambar 3 berikut ini.

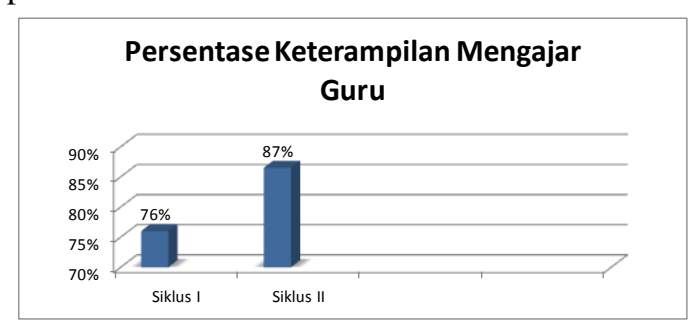

Gambar 3. Diagram Batang Persentase Keterampilan Mengajar Guru
Hasil observasi aktivitas belajar siswa pada siklus I memperoleh persentase $71 \%$ dengan kriteria baik dan meningkat pada siklus II memperoleh persentase $82 \%$ dengan kriteria baik. Untuk memperjelas perbandingan hasil pengamatan aktivitas belajar siswa pada siklus I dan II dapat dilihat pada Gambar 4 berikut ini.

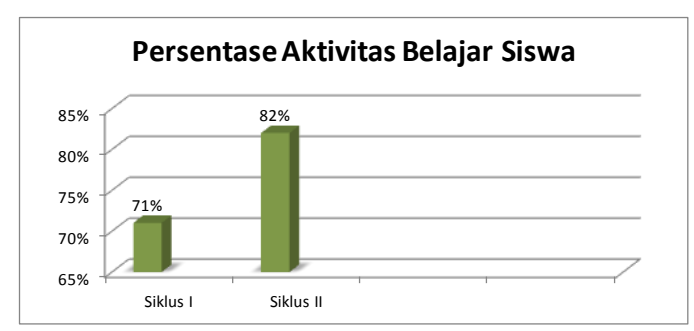

Gambar 4. Diagram Batang Persentase Aktivitas Belajar Siswa

Secara umum kemampuan pemahaman konsep matematika kelas V SD 2 Bae telah mengalami peningkatan yang signifikan dari setiap indikatornya, namun masih ada kelemahan pada indikator membandingkan dan membedakan konsep-konsep. Karena indikator ini membutuhkan kemampuan pemahaman yang tinggi untuk membedakan konsep volume kubus dan volume balok dengan menggunakan alat peraga BongPas yang telah diberikan oleh guru. Sesuai dengan pendapat Hazami (2013:216) matematika adalah aktivitas manusia dan matematika harus dihubungkan secara nyata terhadap konteks kehidupan sehari-hari siswa. Sedangkan RME merupakan model pembelajaran yang bertitik tolak dari hal-hal yang riil bagi siswa, beragrumentasi dengan teman sekelas sehingga mereka dapat menemukan sendiri dan pada akhirnya menggunakan matematika untuk menyelesaikan masalah baik secra individu maupun kelompok.

Keterampilan mengajar guru dalam mengelola pembelajaran meningkat dari siklus I ke siklus II disebabkan karena penggunaan model RME berbantu alat peraga BongPas. Kedua hal itu terbukti sangat efisien terhadap siswa, karena siswa menjadi lebih aktif ketika pembelajaran di kelas, tidak gaduh ketika mengikuti pembelajaran, siswa menjadi lebih kreatif ketika menyelesaikan soal yang berkaitan dengan volume kubus dan balok berbantu alat peraga Bongpas yang telah diberikan oleh guru. Rochmatika (2015:3) keterampilan mengajar guru harus dimiliki agar dalam proses pembelajaran diharapkan dapat menarik perhatian peserta didik. Kemamppuan guru dalam menguasai bahan pelajaran, menguasai kelas, menggunakan berbagai alat peraga dan sumber belajar, memiliki keterampilan 
mengajukan pertanyaan, maka akan tercipta keharmonisan dalam proses belajar mengajar.

Selanjutnya setelah keterampilan mengajar guru dalam mengelola pembelajaran, aktivitas belajar siswa di kelas V SD 2 Bae juga mengalami peningkatan yang signifikan dari siklus I ke siklus II dengan menggunakan model Realistic Mathematic Education berbantu alat peraga BongPas. Siswa menjadi lebih fokus ketika pembelajaran berlangsung, siswa lebih antusias ketika menggunaka alat peraga BongPas karena menurut mereka tidka pernah menggunakan alat peraga yang cocok dengan materi yang diajarkan. Siswa lebih mudah memahami materi yang telah diajarkan guru. Terjalin interaksi yang bagus antara siswa dengan siswa, guru dengan siswa, siswa dengan kelompok. Masruroh (2013:3) bahwa alat peraga atau media pembelajaran dapat digunakan untuk menyalur pesan dari guru ke siswa, agar dapat merangsang siswa untuk belajar lebih bermakna serta menjadikan siswa dapat aktif dalam proses pembelajaran di kelas dan dapat mematangkan pemahaman konsep siswa.

Peningkatan kemampuan berpikir kreatif matematika dengan menggunakan model Realistic Mathematic Education berbantu alat peraga BongPas ini sesuai dengan penelitian yang telah dilakukan oleh Anggareni (2014) yang melakukan penelitian dengan menggunakan kubus satuan dapat meningkatkan kemampuan pemahaman konsep siswa pada materi volume kubus dan balok. Selanjutnya Masruroh (2013) yang melakukan penelitian dengan media bongkar pasang dapat meningkatkan semangat belajar pada mata pelajaran matematika. Yuliyanti (2007) melakukan penelitian dengan menggunakan model Realistic Mathematic Education dapat meningkatkan kemampuan pemahaman konsep siswa.

\section{SIMPULAN}

Berdasarkan penelitian tindakan kelas yang telah dilakukan dapat disimpulkan penggunaan model Realistic Mathematic Education berbantu alat peraga BongPas dapat meningkatkan keterampilan guru dalam mengelola pembelajaran, aktivitas belajar siswa dan kemampuan pemahaman konsep matematika. Peningkatan tersebut dapat dilihat dari hasil penelitian sebagai berikut. (1) Keterampilan mengajar guru dalam mengelola pembelajaran pada siklus I memperoleh persentase $76 \%$ dengan kriteria baik sedangkan siklus II memperoleh persentase $86,5 \%$ dengan kriteria sangat baik. (2) Aktivitas belajar siswa di kelas pada siklus I memperoleh persentase $71 \%$ dengan kriteria baik, sedangkan siklus II memperoleh persentase $82 \%$ dengan kriteria sangat baik. (3) Kemampuan pemahaman konse matematika siswa pada siklus I memperoleh persentase $35,7 \%$ denagn kriteria kurang, sedangkan siklus II memperoleh persentase 78,5\% dengan krriteria baik.

\section{UCAPAN TERIMAKASIH}

Penulis mengucapkan terimakasih kepada Rektor Universitas Muria Kudus yang telah memberikan perijinan untuk melaksanakan penelitian ini. Selain itu penulis juga mengucapkan terimakasih kepada segenap tim Pengelola Jurnal Anargya yang telah memberikan kesempatan kepada penulis untuk mempublikasikan karya ilmiahnya

\section{DAFTAR PUSTAKA}

Alfirdausi, abdul Hadi. 2011. pengaruh Penggunaan Alat Peraga Kartu Kotif (Koin Positif Negatif) Terhadap Hasil Belajar Matematika Siswa. Jurnal Pendidikan Universitas Islam Negeri Syarif Hidayatullah. 14 (1): 178-180.

Angraeni, Darwis dan Gnadung Sugita. Peningkatan Pemahaman Konsep Siswa pada Materi Volume Kubus dan Balok Menggunakan Alat Peraga di Kelas V SDN Pebatae Kecamatan Bumi Raya Kabupaten Morowali. Jurnal Kreatif Tadalako Online, 1 (1), ISSN 2354-614X.

Hazami dan Nida Jarmita. 2013. Ketuntasan Hasil Belajar Siswa Melalui Pendekatan Realistic Mathematics Education (RME) pada Materi Perkalian. Jurnal Ilmiah Didaktika Februari 2013, 13 (2): 212222.

Hobri. 2009. Model-Model Pembelajaran Inovatif. Jember: Center for Society Studies.

Ilma, Ratu dkk. 2007. Pengembangan Materi Kesebangunan Dengan Pendekatan PMRI di SMP Negeri 5 Talang Ubi. Jurnal Pendidikan Matematika, 1 (2): Juli 2007.

Lestari, Karunia Eka. 2015. Penelitian Pendidikan Matematika. Bandung: Refika Aditama.

Masruroh, Intan dan Purwanto. 2013. Meningkatkan Hasil Belajar Matematika Materi Kesebangunan Dengan Menggunakan Media Bongkar Pasang Bangun Datar di Sekolah Dasar. JPGSD 1 (2): 0-216.

Pujiati. 2004. Penggunaan Alat Peraga dalam Pembelajaran Matematika SMP. Jogja: Depdiknas.

Rahayu, Setya. 2012. Pengaruh Pendekatan Realistic Mathematic Education Terhadap 
Pemahaman Konsep Matematika Siswa Kelas VII Madrasah Tsanawiyah Hasanah Pekanbaru. Jurnal Pendidikan Universitas Islam Negeri Sultan Syarif Kasim Riau. 5 (3). Juli 2012.

Rochmatika, Yuliana Oki. 2015. Pengaruh Persepsi Siswa Tentang Keterampilan Mengajar Guru dan Minat Belajar Terhadap Keaktifan Siswa Dalam Proses Pembelajaran Ekonomi Kelas X IPS SMA Negeri 3 Sukoharjo Tahun Ajaran 2014/2015. Jurnal Pendidikan Universitas Muhammadiyah Surakarta.

Susanto, Ahmad. 2013. Teori Belajar dan Pembelajaran di Sekolah Dasar. Jakarta: Kencana Prenamedia Group.

Widari, I Gusti Ayu Arista, dkk. 2013. Penerapan Pendekatan Pembelajaran Matematika Realistik Sebagai Upaya Meningkatkan Aktivitas dan Prestasi Belajar Siswa Dalam Pembelajaran Bangun Ruang pada Siswa Kelas IVA SDN 9 Sesetan Tahun Pelajaran 2011/2012. Jurnal Santiaji Pendidikan, 3 (2): Juli 2013. ISSN 2087-9016.

Yuliyanti, Sri. 2007. Penerapan Realistic Mathematic Education (RME) untuk Meningkatkan Pemahaman Konsep Pecahan pada Siswa Sekolah Dasar. Jurnal Media Pendidikan Matematika. 1 (2): ISSN 2338-3836. 